DOI: 10.17707/AgricultForest.61.3.21

\author{
Maja VUJČIĆ, Jelena TOMIĆEVIĆ-DUBLJEVIĆ, \\ Dragica OBRATOV-PETKOVIĆ, Mirjana OCOKOLJIĆ
}

\title{
INFLUENCE OF MEDICAL PLANTS ON HUMAN HEALTH AND URBAN ENVIRONMENT
}

\begin{abstract}
SUMMARY
City of Belgrade falls into one of the most vulnerable cities in Europe according to the official reports in two studies published by the City Institute for Public Health (CIPH) and Department for Environmental Protection of 2012. Reports are related to the general physical and mental health condition of the residents of city municipalities and the evaluation of environmental quality. According to results of these two studies, municipalities Savski Venac, Stari Grad and Vračar stood out as the most vulnerable in Belgrade. Among selected municipalities Savski Venac has registered the most patients suffering from respiratory system nearly 100 percent and nervous system about 12 percent and measured the highest level of air pollution $\left(\mathrm{CO} 7,36 \mathrm{mg} / \mathrm{m}^{3}\right)$ and noise (Day 73 dBA - Night $69 \mathrm{dBA})$.

Introducing varies medical plant species that are adapted to the urban settings represents sustainable natural mechanism for conservation human health and urban environment. Plants such as South European flowering ash (Fraxinus ornus L.), black elder (Sambucus nigra L.), European larch (Larix decidua Mill.) combined with lungwort (Pulmonaria officinalis L.), ground-ivy (Glechoma hederacea L.) and oregano (Origanum vulgare L.) with their bio-ecological activities, could affect the control and reduction of contamination the urban area and contribute to the health balance.
\end{abstract}

Key words: medical plants, human health, urban environment, municipality, Belgrade

\section{INTRODUCTION}

According to the Aarhus Convention on human rights to appropriate living environment, every person has a right to live in the environment that is adequate to their health and well being, both individually and in community with the others (Đorđevic and Đereg 2006). In order to achieve these rights man should have the access to the information about elements of the environment such as air quality and atmosphere, water, soil, landscape, natural complexes etc. (Đorđevic and Đereg 2006). Defined to the Law of the Environmental Protection, article

\footnotetext{
1 Maja Vujčić (corresponding author: maja.vujcic@yahoo.com), Jelena Tomićević-Dubljević, Dragica Petković-Obratov, Mirjana Ocokoljić, Department for Landscape architecture and horticulture, Faculty of Forestry, University of Belgrade, Kneza Viseslava 1, 11000 Belgrade, SERBIA

Note: The authors declare that they have no conflicts of interest. Authorship Form signed online.
} 
No. 3, the environment represents the set of natural and created values whose complex mutual relations are affecting the environment and living conditions.

Urban vegetation has a principal role in maintaining urban environment desirable for people and everyday life. The presence and distribution of plants in the urban areas depend on the environmental factors that are often in conflict with the anthropogenic, because human necessity to build and live in more urban areas, sometimes takes hold of free green space. The exploitation of urban capacities has direct influence on human health and living environment, also affecting the quality of urban vegetation (Anastasijević, 2007).

The weakened plant metabolism can lead to permanent damage, and without resources of fresh water, air and soil, plants can gradually disappear. To avoid these consequences in designing green spaces, it is important to select the plants that can adjust and resist to the environmental pollution (Anastasijević, 2007). If we could compare the quality of living environment with human health, we would become aware of empathic connection between all organisms living in common area. According to the hypothesis of one English study, how people migration to greener areas can affect their mental health, it was noticed that the experimental group, relocated to a greener areas, recorded a significant improvement in mental and physical condition as well as in private and business spheres, compared to the control group that was moved to the less green areas (Alcock et al. 2013). Relying on the theory that environment can influence on the health and welfare of people, it is possible to represent the connection between man and urban environment through an overview of clinical health reports of the residents of Belgrade municipalities.

\section{MATERIAL AND METHODS}

With the analysis of the evidence lists of health facilities Belgrade municipalities it is presented a description of the state of health, which refers to the review of the physical and mental characteristics of the population of Belgrade. The data cover the reports of preschool and school-aged children and adults reports, presented in the form of Morbidity list of patients suffering from the respiratory system and nervous system. Reports are part of the statistical overview of health services for the 2012, the City Institute of Public Health (CIPH), which are made based on data from health care institutions in Belgrade, primarily health facilities (Tošović, 2013). Reviews of medical reports were compared with the reports of the Census of Population, Households and Dwellings in 2011 in the Republic of Serbia, which are available on the official website of the Republic Institute for Statistics, for the percentage formulation of data. Also view of reports from The City Department for Environmental Protection, represent the environmental noxae such as the level of air pollution and noise measured in the Belgrade (ГЗЈ3, 2012).

\section{Urban ecosystem and human health}

During the social development men was changing natural environmental conditions. There was a disturbance of the natural balance, which is reflected in a 
dozen attitudes defined in terms of environmental degradation, including the disappearance of a prominent extinction of many populations of plants and animals and jeopardizing the existing ones, as well as increasing disease and mortality, which is caused by environmental pollution (Blagojević, 2003). Using the two parameters, the registered population of patients of respiratory disorders and nervous disorders and the evaluation of air quality and noise, by direct crossing, it was presented a description of the physical and mental health of the citizens of central Belgrade municipalities. It was emphasized that the two parameters that are taken into consideration are not random, but interconnected.

In addition to the analysis of health reporting population in order to highlight the most vulnerable municipalities in Belgrade, there were studied and introduced plant species of urban ecosystems. The criteria have been subjected to selection of plants, based on the natural characteristics of woody and herbaceous species. The selected plants have a positive effect on the respiratory system, and its physiognomy and natural features positively affect the mental state of people (Ilijev and Lazarević 2010). Besides natural and medicinal characteristics of plant species, it was primarily taken into account and emphasized their suitability to urban areas, and their presence and immediate impact on the biological factors and microclimate of certain parts of the city as a unique mechanism for health of residents of affected municipalities.

\section{RESULTS AND DISCUSSION}

Socio-demographic and health characteristics of urban households have changed under the influence of a variety of historical, political and social factors, and their effects can be presented using the ecological and medical description of Belgrade municipalities (Jelić, 2015). Municipalities that have the highest percentage of registered patients with respiratory disorders are also municipalities that have the lowest air quality (Table 1).

Municipalities with the highest percentage of registered patients with nervous disorders are also municipalities that have measured the highest level of sonar pollution (Table 2).

Such data indicates the three municipalities that include municipalities Savski Venac, Stari Grad and Vračar, among which has highlighted Savski Venac as one of the central municipality with the highest percentage of patients and environmental degradation. Municipalities of Stari Grad and Vračar interspersed by percentage on both Tables, but still occupy high positions quoted in relation to the other investigated municipalities. Based on available data indicating that the preconditions for developing illness among the people, doesn't have to be related to degree of development of municipalities, population or their surface. The reason for this view of the situation is not only a medical problem, but also a consequence of a life style of inhabitants of these municipalities (Asberg et al. 2013). Taking into consideration that improving the quality of life can be achieved through plants or their ecological and physiological traits, further in this paper are presented woody and herbaceous plants, which can contribute to 
environmental improvement of the immediate environment of affected communities and residents and have a direct impact on the improvement of their physical and mental state (Lewis, 1977).

Table 1. Overview of patient reports for respiratory disorders combined with the highest concentrations of airborne pollutants registered at the measuring points (CIPH, 2012)

\begin{tabular}{|c|c|c|c|c|c|c|}
\hline & Municipalities & $\begin{array}{c}\text { Measuring } \\
\text { points }\end{array}$ & $\begin{array}{l}\text { Standard } \\
\text { for } \mathrm{CO} \\
\left(3 \mathrm{mg} / \mathrm{m}^{3}\right)\end{array}$ & $\begin{array}{c}\text { Standard for } \\
\mathrm{SO}_{2} \\
\left(40 \mathrm{mg} / \mathrm{m}^{3}\right)\end{array}$ & $\begin{array}{c}\text { Standard for } \\
\mathrm{NO}_{2} \\
\left(50 \mathrm{mg} / \mathrm{m}^{3}\right)\end{array}$ & $\begin{array}{c}\text { Respiratory } \\
\text { disorders }(\%)\end{array}$ \\
\hline 1. & Savski Venac & $\begin{array}{l}\text { Main } \\
\text { Railway } \\
\text { station }\end{array}$ & 7,36 & 133,8 & 105,2 & $\approx 100$ \\
\hline 2. & Stari Grad & $\begin{array}{c}\text { National } \\
\text { Assembly }\end{array}$ & 7,12 & 144,8 & 103,7 & 84 \\
\hline 3. & Vračar & $\begin{array}{l}\text { London } \\
\text { (corner) }\end{array}$ & 6,06 & 96,3 & 106,6 & 81 \\
\hline
\end{tabular}

Notification: It is notable that the top of the table is characterized by an extremely high percentage terms, some over 100 percent, which only shows that in these municipalities there are a number of chronic patients, who, during the observation period, had more consultation with the doctor

Table 2. Overview of patient reports for nervous disorders combined with the highest level of noise registered at the measuring points (CIPH, 2012)

\begin{tabular}{|c|c|c|c|c|c|}
\hline & Municipalities & $\begin{array}{c}\text { Measuring } \\
\text { points }\end{array}$ & $\begin{array}{c}\text { Standard } \\
\text { for day } \\
(55-65 \\
\text { dBA })\end{array}$ & $\begin{array}{c}\text { Standard } \\
\text { for night } \\
(45 \mathrm{dBA})\end{array}$ & $\begin{array}{c}\text { Nervous } \\
\text { disorders } \\
(\%)\end{array}$ \\
\hline 1. & Savski Venac & $\begin{array}{c}\text { Karađorđeva } \\
\text { street }\end{array}$ & 73 & 69 & 12 \\
\hline 2. & Stari Grad & $\begin{array}{c}\text { Uzun Mirkova } \\
\text { street }\end{array}$ & 74 & 60 & 5 \\
\hline 3. & Vračar & $\begin{array}{c}\text { Bul.Kralja } \\
\text { Aleksandra } \\
\text { street }\end{array}$ & 69 & 66 & 4,4 \\
\hline
\end{tabular}

Plants have a positive influence on human health in reducing air pollution and noise, enhancing microclimate of living and working space, providing phytoncide effects and improving general physical and mental health (Đukić, 2000). The selection of the plant species, which are highly resistant to the urban conditions, can improve the ecological status of the individual municipalities and the whole city. By reducing the air pollution, plants have positive influence on respiratory system and the refined areas provide therapeutic effects on people with mental and behavioral disorders.

\section{The influence of woody plants on microclimate}

The combination of the deciduous and coniferous trees represents the best solution for refinement of urban areas. The deciduous tree crown has 
multifunctional effects such as providing shade, accumulating air polluters, perfuming atmosphere, and best species for that are South European flowering ash (Fraxinus ornus L.), Small-leaved Linden (Tilia cordata Miler.), large-leaved linden (Tilia platyphyllos Scop.), ginkgo (Ginkgo biloba L.), the dog-rose (Rosa canina L.), black elder (Sambucus nigra L.) and common ivy (Hedera helix L.) (Vukićević, 1996). The coniferous species are most associated to the mountain areas. They are often used in designing hospital complexes because they are providing a sense of peace and relaxation, and the recommended species are the Atlas cedar (Cedrus atlantica L.), European larch (Larix decidua Mill.) and Serbian Spruce (Picea omorika Pančić.) (Vukićević, 1996). It is known that the deciduous trees have no crown during the whole year and that their function does not end with that. According to the surveys that are conducted in order to measure the presence of air polluters in urban areas, the quality of the atmosphere is presented through the amount of mechanical particles in a tree and for the ash the amount was $27 \mathrm{~kg}$ in vegetation periods, which significantly affects the purification of urban air (Bobohidže, 1965). Ginkgo and common ivy represent good air pollute collectors because they have leafs trough the whole vegetation season. The presence of the dog rose and black elder in urban areas has bio ecologic use, because they belong to species that possess resistance to air pollutants, binding them to harmful gases and dust and also help to purify the air. Depending on the width of the buffer zone, they provide different effects as measured on the ground and in the air, where it emphasizes black elder, which is the effective accumulation of sediment air pollute particles on the surface of leaves and branches, during one vegetation period is $0.4 \mathrm{~kg}$ (Babajanc, 1948, Bobohidže, 1965, Berry, 1968, Smith, 1981, Anastasijević and Vratuša, 1999). Small-leaved and large-leave lindens make quite a widespread species in urban areas, especially Belgrade, and may meet as an integral part of the urban landscape. Highlights their bio-ecologic multifunctional effects and due to that they have ideal habitat level of coverage or overshadow amounts up to 94 percent. In this way, Small-leave Linden affects the reduction of heating surfaces, by reflecting 72 percent of the total amount of energy it receives, thus the difference in the amount of missed and reflected energy by the canopy provides a coefficient albedo of 23 percent (Bobohidže, 1965). Large-leave linden has observed phytoncide properties that are reflected in the possibility of eliminating some types of bacteria and preventing their further development in the air (Gorlenko, 1972).

Coniferous species such as the Atlas cedar and European larch, contribute to air refinement, emitting a very pleasant smell, which serves to mask unpleasant odors in public areas. The Atlas cedar expressed phytoncide effect by emitting phytoncides that destroy up to tree bacteria after one-minute stay in the air above the plants. European larch represents small oxygen factory, contributing to an annual level of $15.5 \mathrm{t} / \mathrm{ha} / \mathrm{yr}$. (Bernatzky, 1989). It was concluded that width the 20 meters harnesses made up of five rows sawmills (e.g. spruce) and two rows of shrubs (e.g. the dog-rose), provide the best effects in 
reducing noise levels and protecting citizens from sonorous pollution (Bolhovitina, 1973).

\section{The influence of herbaceous plants on microclimate}

In addition to woody plants impact on the microclimate conditions of the city also have herbaceous plants. The visual effects in the form of color, appearance and texture contribute to the aesthetics of the area but the fragrances that characterize them, contribute to air perfume and refinement process in the city. Flowering of selected species alternates so that the presence of flowers in a large part of the year had an almost continuous string. In addition to their decorative side, aromatic plants are characterized by healing properties, which contribute to the therapeutic effect in the city and include plant species like Lily of the valley (Convallaria majalis L.), chamomile (Matricaria chamomilla L.), lungwort (Pulmonaria officinalis L.), common centaury (Centaurinum umbellatum L.), showy savory (Calamintha officinalis L.), ground-ivy (Glechoma hederacea L.), lemon balm (Melissa officinalis L.), oregano (Origanum vulgare L.), betony (Stachys officinalis L.), wall germander (Teucrium chamaedrys L.), mountain germander (Teucrium montanum L.), common thyme (Thymus vulgaris L.), marsh-mallow (Althaea officinalis L.), cowslip (Primula veris L.), sweet woodruff (Asperula odorata L.) and wood violet (Viola odorata L.). From the general characteristics of selected herbaceous species most among are the perennial, except chamomile and common centaury as annual species. Plant height is ranging from $10 \mathrm{~cm}$ to $150 \mathrm{~cm}$, so that the proper planting ideally filled environment and provide harmony in space and the eye of the beholder. In addition to texture, plant with its colors tone the living environment of inhabitants, visually enriching the urban environment. The main ecological functions of herbaceous plants are linked to the air refinement, because their characteristic odors mask unpleasant smells and contribute to air quality of urban environment (Obratov-Petković and Đukić 2000, Živanović and Pavlović 1995).

\section{CONCLUSION}

With the introduction of medical reports inhabitants of Belgrade City Institute for Public Health, referring to those who are suffering of the respiratory disorders and nervous disorders, the doctors themselves drew attention to the most vulnerable Belgrade municipality. One of the mechanism to improve the general physical and mental condition of the inhabitants of Belgrade municipalities, are plants with their bio-ecological activities they could affect the control and reduction of contamination of the urban area. Plants with its multifunctional effects are natural regulators to improve the quality of the urban microclimate and human health. Using the system for the accumulation of harmful particles Tilia cordata, Fraxinus ornus, Rosa canina and Sambucus nigra, and with the production of oxygen woody species like Picea omorika, Cedrus atlantica, and Larix decidua, directly impact on improving air quality. 
Herbaceous species like Matricaria chamomilla, Thymus vulgaris, Melissa officinalis and Convallaria majalis, emit pleasant odors and enrich the living environment of city residents. The combination of woody and herbaceous plants that are characterized by aromatic medicinal properties enhances the bioecological state of urban areas and raises the overall health of people at a higher level. In order to identify the positive effects it is necessary a certain period of time, but their healing effect is undoubted, given that similar initiatives were implemented in European urban centers of England, Sweden, the Netherlands and others. Short-term effects would comprise of expanding the living space of the citizens of Belgrade municipalities, construction of new landscaped areas for living and socializing. Long-term effects would be gradually implemented and would represent enhancement in the habits of citizens, which would have direct impact on improving their health and wellbeing.

\section{REFERENCES}

Alcock, I., White, P.M., Wheeler, W.B., Fleming, E.L. and Depledge, H.M. (2013): Longitudinal Effects on Mental Health of Moving to Greener and Less Green Urban Areas, Environmental Science and Technology, 48 (2), pp. 1247-1255.

Anastasijević, N. \& Vratuša, V. (1999): Utvrđivanje stepena funkcionalnosti ukrasnih drvenastih vrsta. Monografija Zaštita životne sredine gradova i prigradskih naselja, tom I. Ekokonferencija 99, 22-25 septembar, 1999, Novi Sad, pp. 439-444.

Anastasijević, N. (2007): Podizanje i negovanje zelenih površina, Šumarski Fakultet, Beograd, pp. 75-80, 81-87.

Asberg, M., Nygren, A. and Nager, A. (2013): Distinguishing between depression and exhaustion disorder, Lakartidningen, 10, pp. 484-486.

Babajanc, R.A. (1948): Zagraznenie gorodskogo vazduha, Akad. Medic. Nauk SSSR, Moskva.

Bernatzky, A. (1989): Tree ecology and preservation, III edition, Elsevier, Amsterdam.

Berry, C.R. (1968): Air pollution detectives, Yearbook of Agriculture, USDA, Washington.

Blagojević, B. (2003): Zagađena životna sredina i lekovite biljke, Fakultet zaštite na radu, Niš.

Bobohidže, N.V. (1965): Zeleni nasaždenija i mikroklimat teritorii, Gorodsko hozjajstvo, br. 5.

Bolhovitina, M. M. (1973): Isledovanije vlijanija zelenih nasaždenija na sniženie šuma gorodskih teritorii, Lesoteh, akademija im. S. M. Kirova, Leningrad.

Đorđević, S. \& Đereg, N. (2006): Arhuska konvencija u Republici Srbiji: učešće javnosti u procesu donošenja odluka o životnoj sredini - studije slučaja, Brošura projekta: "Unapređenje prakse učešća javnosti: koraci ka primeni Arhuske konvencije",REC, Beograd, pp. 11-13.

Đukić, M. (2000): Hortikulturno inženjerstvo u zaštiti životne sredine i zdravlja ljudi, Ecologica, Beograd, 2, pp. 147-152.

ГЗЈ3 (2012): Квалитет животне средине града Београда у 2011. години, 
Секретаријат за заштиту животне средине, Регионални Центар за животну средину (РЕЦ), Београд.

Gorlenko, S.V. (1972): Funkgcidnie svojstva nekotorih drevesnih i kustarnikovih porod, Stroizdat, Moskva.

Ilijev I. \& Lazarević K. (2010): Bezbednost primene proizvoda od lekovitog bilja u psihijatriji, članak-sastavni deo, Apollinem medicum et Aesculapium, 8 (1), pp. 6-10.

Jelić, S., Jandrić, M., Živković, D. and Milovančević, Z. (2015): Determination of household and regional rural development, Agriculture and Forestry, 61 (1), pp. 143 - 148, Podgorica.

Lewis, A.Ch. (1977): Human perspectives in horticulture, Children, Nature, and the Urban Environment: Proceedings of a Symposium-Fair, General Technical Reports, pp. 187-190.

Obratov-Petković D. \& Đukić M. (2000): Mala flora Avale: monografija, Beograd.

Smith, V.H. (1981): Air pollution and forests, Springer Verlag, New York.

Tošović, S. (2013): Statistički prikaz zdravstvene delatnosti u Beogradu za 2012. godinu, Gradski zavod za javno zdravlje, Beograd, pp. 61-111, 113-161, 187-221.

Vukićević, E. (1996): Dekorativna dendrologija, Šumarski Fakultet, Beograd.

Zakon o zaštiti životne sredine, "Sl. glasnik RS", br. 135/2004, 36/2009, 36/2009 - dr. zakon i 72/2009 - dr. zakon. Član 3.

Živanović, P. \& Pavlović, S. (1995): Sistematika lekovitih biljaka, Praktikum, Beograd. 